\title{
Nadir bir hastalık; spontan pnömotoraks ile başvuran Erdheim-Chester hastalığı
}

\author{
Mustafa Buğra \\ COȘKUNER ${ }^{1}$ \\ Tevfik ÖZLÜ1 \\ Yılmaz BÜLBÜL ${ }^{1}$
}

${ }^{1}$ Karadeniz Teknik Üniversitesi Tıp Fakültesi, Göğüs Hastalıkları Anabilim Dalı, Trabzon, Türkiye

${ }^{1}$ Department of Chest Diseases, Faculty of Medicine, Karadeniz Technical University, Trabzon, Turkey
Makale Atıfı: Coşkuner MB, Özlü T, Bülbül Y. Nadir bir hastalık; spontan pnömotoraks ile basvuran Erdheim-Chester hastalı̆̆ı. Tuberk Toraks 2019;67(3):225-30.

\section{Yazışma Adresi (Address for Correspondence)}

Dr. Mustafa Buğra COŞKUNER

Karadeniz Teknik Üniversitesi Tıp Fakültesi, Göğüs Hastalıkları Anabilim Dalı,

TRABZON - TÜRKIYE

e-mail: mustafabugracoskuner@gmail.com
ÖZ

Nadir bir hastalık; spontan pnömotoraks ile başvuran Erdheim-Chester hastalığı

Erdheim-Chester hastalı̆̆ı (ECD) sebebi bilinmeyen köpüksü histiyositlerin organ tutulumu ile karakterize non-Langerhans hücreli histiyositozis formudur. ECD tanısı doku biyopsilerinde tipik olarak CD68+ CD1a- histiyositlerin tespitini içerir. Bu karakteristik histiyositler ECD olgularında hemen her dokuda bulunabilir. Spontan pnömotoraks ve nörolojik tutulum ile başvuran ilginç bir ECD olgusunu sunuyoruz.

Anahtar kelimeler: Histiyositozis; Erdheim-Chester hastalığı; akciğer

\section{ABSTRACT}

A rare disease; Erdheim-Chester disease presenting with spontaneous pneumothorax

Erdheim-Chester disease (ECD) is a rare non-Langerhans histiocytosis of unknown etiology, it is characterized by organ infiltration of foamy histiocytes. Diagnosis of ECD involves the analysis of histiocytes in tissue biopsies: these are typically CD68+ CD1a-. These characteristic histiocytes may be found in almost any tissue in cases of ECD. We present an interesting case of ECD that was presented by spontaneous pneumothorax and neurological involvement.

Key words: Histiocytosis; Erdheim-Chester disease; lung

OTelif Hakkı 2019 Tüberküloz ve Toraks. Makale metnine

www.tuberktoraks.org web adresinden ulaşılabilir. 


\section{GiRiş}

Histiyositozlar, dendritik hücrelerden veya makrofajlardan türediği düşünülen hücrelerin birikmesi ile karakterize nadir hastalıklardır. ilk olarak 1930 yılında Jakob Erdheim ve William Chester tarafından tanımlanan Erdheim-Chester hastalığı, etyolojisi bilinmeyen ve non-Langerhans hücreli histiyositlerin kemik doku başta olmak üzere çeşitli organ ve dokuları infiltre etmesiyle seyreden bir histiyositoz formudur. Son dönemde yapılan çalışmalar neticesinde klinisyenlerin farkındalığı artmış ve bildirilen olgu sayısında artış izlenmiştir. Bugüne kadar bildirilen 600 civarı hasta vardır.

\section{OLGU SUNUMU}

On dokuz yaşında kadın hastada, ani gelişen sırt ağrısı ve nefes darlığı sonucu spontan hidropnömotoraks tespit edildi. Bilgisayarlı tomografi görüntülemesinde bilateral kistik lezyonlar ve retiküler infiltrasyonlar görülmesi nedeniyle tanı ve tedavi amacıyla eş zamanlı wedge biyopsi, tüp torakostomi uygulandı.

Anamnezi derinleştirilen hastanın çocukluk çağından itibaren büyüme gelişme geriliği, hipotiroidi, boş sella sendromu tanıları ile Çocuk Endokrinolojisi tarafından takip edildiği öğrenildi. Özellikle son iki yıldır artış gösteren eforla nefes darlığı, yüksek sesle kitap okuduğunda gelişen öksürük, yürüyüş sonrası ayak ve ayak bileklerinde şiddetli ağrı, sırt ağrısı, halsizlik ve kilo alamama şikayetleri vardı.

Sigara içmeyen hastanın, çevresel maruziyeti yoktu. Apendektomi ve myringoplasti operasyonları geçirdiği öğrenildi. Soygeçmişinde özellik yoktu. Fizik muayenesinde geçirdiği operasyon sekelleri dışında ek patolojik bulgu tespit edilmedi. Akciğer grafisinde bilateral retiküler infiltrasyonlar izlendi (Resim 1).

Solunum fonksiyon testlerinde ağır restriktif kusur $\left(\mathrm{FEV}_{1} 1.04 \mathrm{~L}\right.$, FVC 1.06 L, FEV /FVC \%96) ve DLCO da ileri düzeyde azalma (DLAdj \%24) belirlendi.
Laboratuvar tetkiklerinde; hemoglobin $11.1 \mathrm{~g} / \mathrm{dL}(\downarrow)$, sedimentasyon (1. saat) $73 \mathrm{~mm}(\uparrow)$, alkalen fosfataz 155 $\mathrm{U} / \mathrm{L}(\uparrow)$, total demir $8 \mu \mathrm{g} / \mathrm{dL}(\downarrow)$, total demir bağlama kapasitesi $152 \mu \mathrm{g} / \mathrm{dL}(\downarrow)$, albumin $2.4 \mathrm{~g} / \mathrm{dL}(\downarrow)$ ölçüldü. Bağ dokusu belirteçlerinden romatoid faktör 39.1 IU/ $\mathrm{mL}(\uparrow)$ ve antinükleer antikor 1 (+) ölçüldü. Diğger laboratuvar tetkikleri ve bağ dokusu belirteçlerinde anormallik görülmedi. Lenfanjiyoleiyomiyomatozis (LAM)'e yönelik yapılan ileri tetkikinde vasküler endotelyal büyüme faktörü (VEGF) normal olarak tespit edildi.

Yüksek rezolüsyonlu akciğer tomografisinde bilateral dağınık yerleşimli buzlu cam dansiteleri, retikülasyon artışı, subplevral ve üst loblarda peribronkovasküler alanlarda büyüğü $1.5 \mathrm{~cm}$ çapında kistler, alt loblarda milimetrik sentrilobüler nodüller, sağ hemitoraksta plevral sıvı, sol hemitoraksta pnömotoraks görüldü (Resim 2).

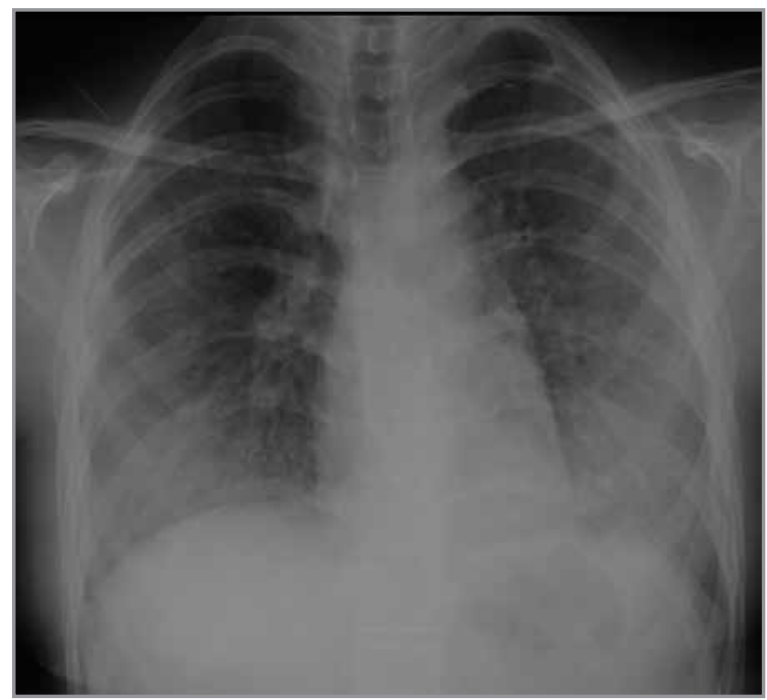

Resim 1. Bilateral orta alt zonlarda retiküler gölgelenmeler, sol üst zonda minimal pnömotoraks hattı.
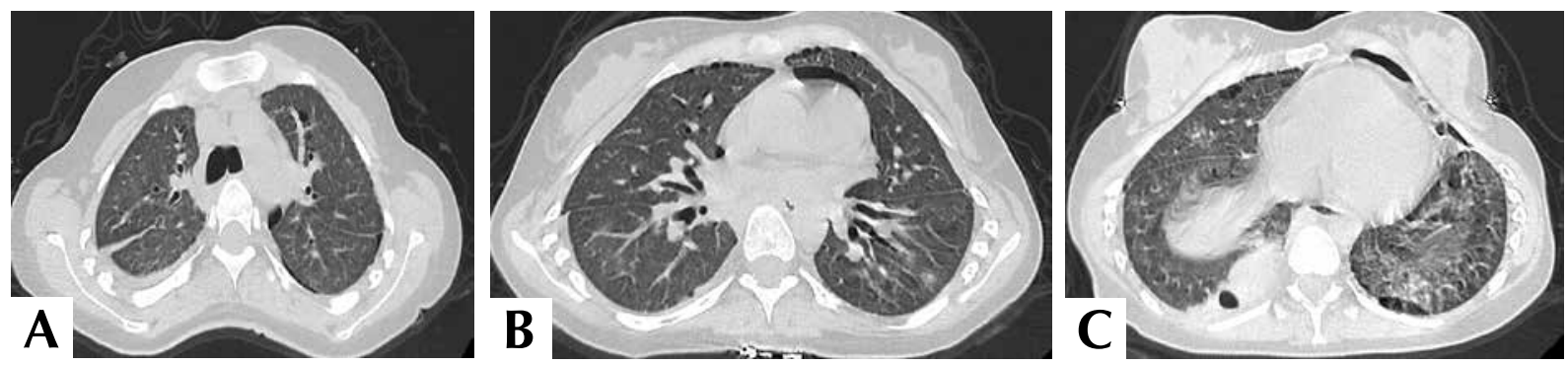

Resim 2. Bilateral dağınık yerleşimli buzlu cam dansiteleri, retikülasyon artışı, subplevral ve üst loblarda peribronkovasküler alanlarda büyügü $1.5 \mathrm{~cm}$ çapında kistler, alt loblarda milimetrik sentrilobüler nodüller, sağ hemitoraksta plevral sıvı, sol hemitoraksta pnömotoraks. 
Sol akciğerden yapılan wedge biyopsi örneğinin histopatolojisinde geniş subplevral büllöz kistler, paraseptal amfizem, interstisyel kollaps, bronşektazi, interstisyel germinal merkezleri belirgin reaktif lenfoid nodüller izlenirken, immünohistokimyasal çalışmada büyük damarların çevresinde normal sınırlarda fibrozis ve bir kısmında ise CD68+ olarak tespit edildi. S100, HMB 45, MelanA, TTF-1, P63, CD31, CD34, D2-40 çalışmaları negatif olarak sonuçlandı. BRAF V600E gen mutasyonu izlenmedi.

Yukarıda belirtilen klinik, radyolojik ve patolojik bulgular ile Erdheim-Chester hastalığı düşünülen olgu- muzda tanıya yönelik görüntülemeler literatür eşliğinde genişletildi.

Kraniyal MR'de bilateral serebral beyaz cevherde ve ponsta T2 ve FLAIR'de hiperintens lezyonlar izlendi. Hipofiz MR'de parsiyel boş sella izlendi. Orbita MR normal olarak izlendi (Resim 3).

Kemik sintigrafisinde T12 ve L1 seviyesinde artmış aktivite tutulumu ve epifiz hatlarında hafif düzeyde simetrik fizyolojik artmış aktivite tutulumu ölçüldü (Resim 4).
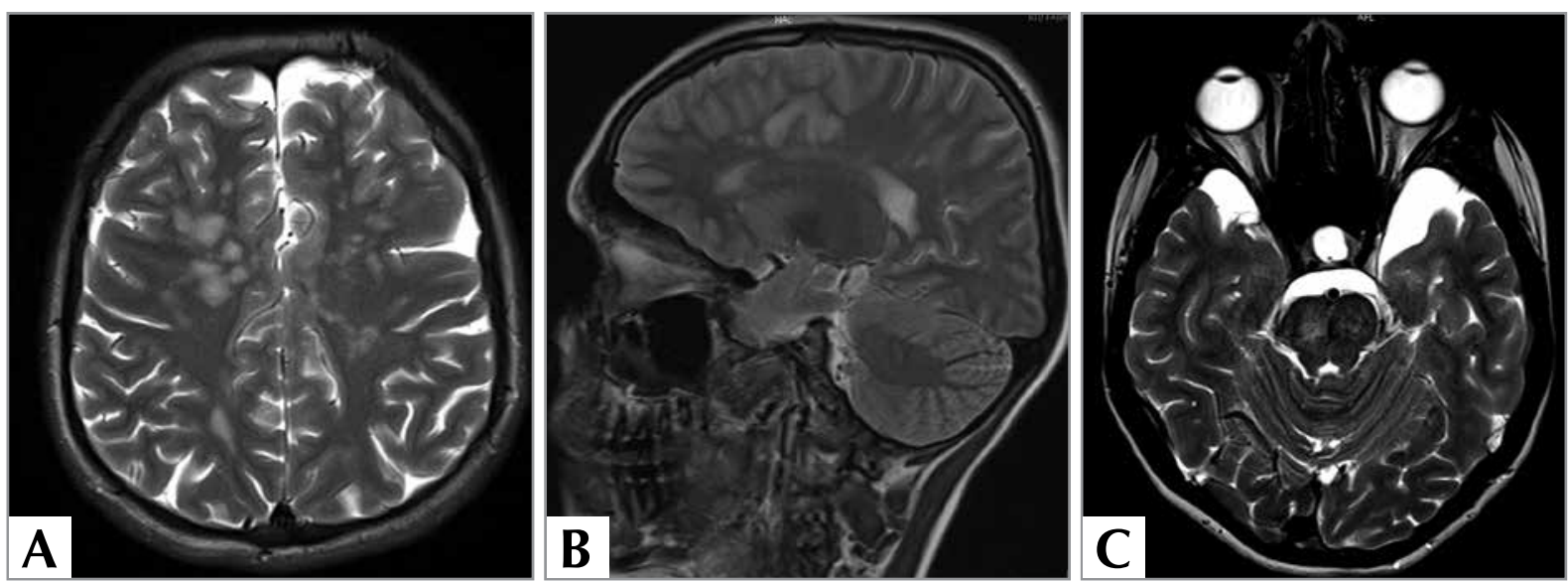

Resim 3. A, B. Kraniyal-Hipofiz MR bilateral serebral beyaz cevherde ve ponsta T2 ve FLAiR'de hiperintens lezyonlar, parsiyel boş sella, C. Orbita MR.

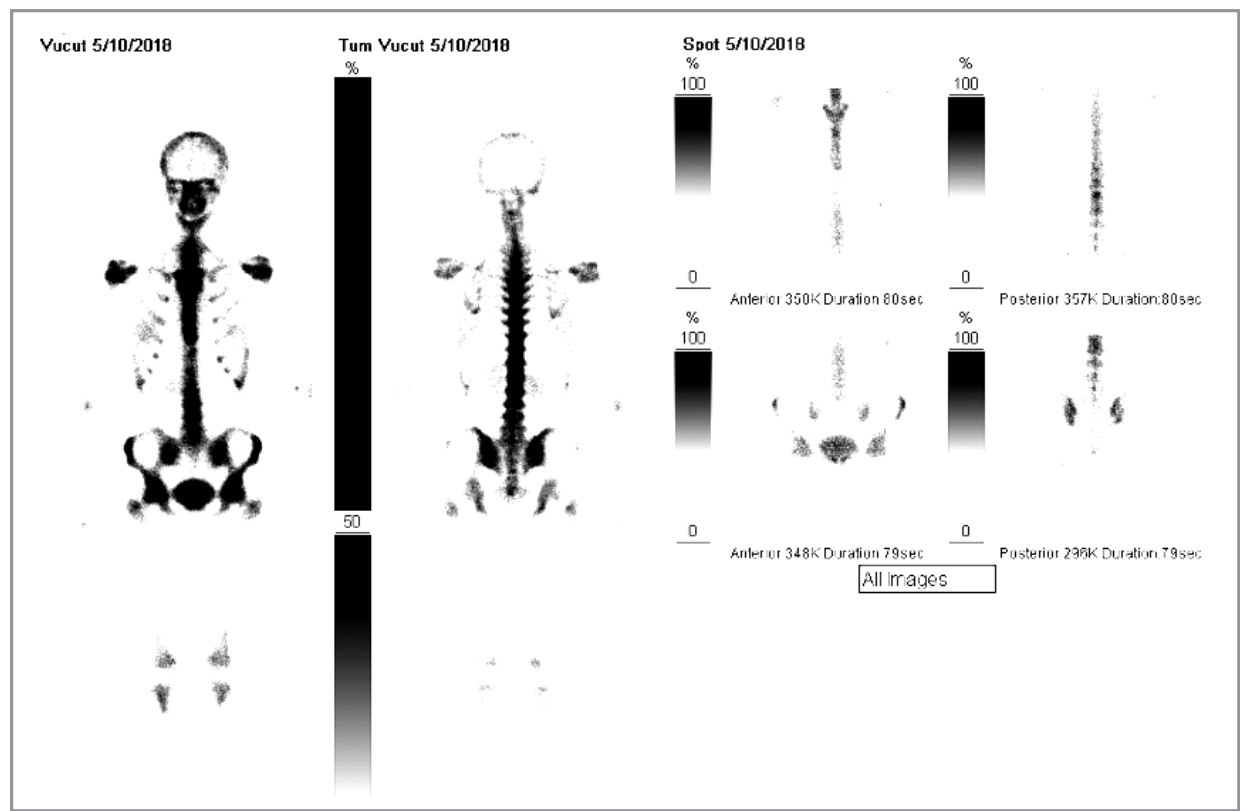

Resim 4. Kemik sintigrafisi T12 ve L1 seviyesinde artmış aktivite tutulumu ve epifiz hatlarında hafif düzeyde simetrik fizyolojik artmış aktivite tutulumu. 
Torakolomber MR görüntülemesinde T12 vertebra gövdesinde hemanjiyom raporlandı.

Ekokardiyografide sol ventrikül diyastolik fonksiyonu tespit edildi. Kardiyak MR ve abdomen BT görüntülemelerinde patolojik bulgu saptanmadı.

Hastaya histopatoloji, görüntüleme ve klinik bulguları ile Erdheim-Chester tanısı konuldu.

Tedavi almayı reddeden hasta bir yıllık takibinde olup klinik, radyolojik ve laboratuvar bulguları ile stabil olarak seyretmektedir.

\section{TARTIŞMA}

Moleküler ve genetik son gelişmeler, ECD hastalarının periferik kan ve biyopsi materyallerinde MEKERK sinyal iletimindeki yaygın neoplazmlar olduğu hipotezini desteklemektedir. Klasik olarak ErdheimChester hastalığı (ECD) nadir görülen ve nedeni bilinmeyen Langerhans hücreli olmayan histiyositozis formu olarak kabul edilmektedir.

LCH'nin aksine ECD, çocuklarda nadir görülüp çoğunlukla yaşlı erkekleri etkilemektedir $(1,2)$.

ECD multisistemik bir hastalıktır. Hastalar kemik ağrıları ile birlikte olan iskelet tutulumu, eksoftalmus, diabetes insipitus, ksantalezma, interstisyel akciğer hastalığı, bilateral adrenal büyüme, retroperitoneal fibrozis, üretral darlık, böbrek hasarı, testis infiltrasyonu, santral sinir sistemi tutulumu, kardiyovasküler tutulum gibi birçok farklı şekilde bulgu verebilir. Hastalık seyri asemptomatik kemik lezyonlarından yaşamı tehdit eden çoklu organ tutulumuna kadar değişkenlik gösterebilmektedir (3).

Hastaların \%20'sinden fazlasında ateş, kilo kaybı, halsizlik, yorgunluk gibi semptomlar mevcuttur (5).

ECD tanısı uygun klinik ve radyolojik bulgular eşliginde histopatolojik olarak konulmaktadır. Haroche ve arkadaşları iki madde ile tanı kriterlerini ortaya koymuşlardır (3):

1. Karakteristik histolojik bulgular: CD68+ CD1aköpüksü histiyositlerin granülomatöz infiltrasyonu ve fibrozis veya ksantogranülomatozis,

2. Karakteristik iskelet anormallikleri: a. X-ray görüntülemesinde uzun kemiklerin diyafiz ve metafiz bölümlerinin bilateral ve simetrik kortikal osteosklerozu, b. 99Tc kemik sintigrafisinde bacaklardaki ve bazen kollardaki uzun kemiklerin distal uçlarının ve yoğun tutulumu.
ECD hastalarının hemen hemen tamamında kemik tutulumu vardır. Ancak hastaların sadece \%50'si kemik ağrısından şikayetçidir. ECD daha çok alt ekstremitede sklerotik kemik lezyonlarına neden olurken; daha çok kafatası, yüz, üst ekstremite, pelvis ve skapula tutulumuna neden olan LCH'den bu yönüyle farklılık göstermektedir (3-5). Olgumuzda görülen vertebra tutulumu ECD hastalarında nadiren görülmektedir (6).

Pulmoner tutulum genellikle asemptomatiktir. Ancak prognozu etkilediğinden klinik açıdan önemlidir. Semptomatik hastalarda en sık öksürük ve dispneye neden olmaktadır. Spirometride restriktif patern ve azalmış difüzyon kapasitesi görülebilmektedir. Direkt grafinin duyarlılığı düşüktür. Yüksek rezolüsyonlu BT ile akciğer değerlendirmelerinde \%50'ye varan oranlarda interstisyel infiltrasyonlar, buzlu cam opasiteler, sentrilobüler nodüller gösterilmektedir. Konsolidasyon nadiren görülmektedir. ECD'nin akciğer infiltrasyonu visseral plevra, interlobüler septa ve bronkoalveoler ağacı izleyen tipik bir lenfanjitik yayılım gösterir $(4,5)$. Olgumuzda da görülen bilateral küçük mikrokistler bronşiyal distorsiyonla ilişkili olarak hastaların $\% 12$ 'sinde bulunabilir (7). Bildirilen spontan pnömotoraks olgusu nadirdir. Bronkoalveoler lavaj sIvısı histolojik değerlendirme ile tanıya katkı sağlayabilir $(4,5)$.

Nörolojik tutulum ECD hastalarının prognozunda önemlidir. Bağımsız bir mortalite riski göstergesidir. Tedaviye zayıf yanıt verir. Hastaların \%50'sinde santral sinir sistemi tutulumu görülmektedir. Bu yüksek prevalans nedeniyle yeni ECD tanısı alan hastalara kraniyal görüntüleme yapılması gereklidir.

Diabetes insipidus, eksoftalmos, serebellar ataksi, panhipopitutiarizm ve papilödem en sık görülen nörolojik bulgulardır. Kontrastlı MR görüntüleme ve BT tercih edilen görüntüleme teknikleridir. Nöroaksis boyunca hem intraaksiyel hem ekstraaksiyel tutulum görülebilir. Meningioma, LCH, granülomatöz hastalıklar gibi pakimeninksi tutan lezyonlar görülebilir. Nükleus dentatusu ve pons, intraaksiyel en sık tutulan bölgelerdir. Görüntüleme benzerliği nedeniyle lezyonların demiyelinizan hastalıklardan, metastazlardan, lökodistrofilerden ve diğer inflamatuvar durumlardan ayırt edilmesi gereklidir $(4,5,8)$.

Meningeal tutulum, hastaların \%23'ünde tek veya çoklu dural kitleler veya yaygın pakimeningial kalınlaşma şeklinde ortaya çıkar. Intraaksiyel tutulum supratentoryal veya infratentoriyal bölgede bir veya 
birden fazla kitle lezyonu gösterir. Bu meningeal ya da intraaksiyel lezyonlar tipik olarak T2 ağılıklı görüntülerde bir izo-hipointens sinyali ve gadolinyum ile güçlendirilmiş T1 ağırlıklı görüntülerde yoğun homojen bir artış sergiler (8).

ECD hastalarının \%25'inde sıklıkla bilateral veya unilateral orbita tutulumları görülürken, eksoftalmus, retroorbital ağrı, basıya bağlı okülamatör sinir felci ve körlüğe neden olabilmektedir $(4,5)$.

Diabetes insipitus hipofiz bezi tutulumuna bağ sık görülen endokrinopatidir. ECD hastalarının $\% 25$ 'inde görülür. Bununla birlikte hiperprolaktine$\mathrm{mi}$, gonadotropin yetmezliği, hipotestosteronizm, insülin benzeri büyüme faktörü eksikliği dahil birçok endokrinopati görülebilir.

İnfiltrasyon ve büyüme ile birlikte adrenal yetmezlikler bildirilmiştir (3-5).

Retroperitoneal dokuların infiltrasyonu sonucu oluşan ve abdominal BT taramasında \%30 oranında saptanabilen "hairy kidney" ECD için tipik bulgulardandır. Retroperitoneal fibrozis klinik olarak sessiz kalabilir, aynı zamanda dizüri, abdominal ağrı ve kronik böbrek yetmezliğine neden olabilen üreter kompresyonunun neden olduğu hidroüreteronefroz gibi ilgili ürolojik komplikasyonlara da yol açabilir (5).

Kardiyovasküler tutulum yaygındır ancak sessiz seyrettiğinden genellikle tesadüfen $B T$ veya MR görüntülemesinde tespit edilebilir. ECD hastalarının en sık ölüm nedenidir. Ekokardiyografide \%40-45 oranında oldukça sık olarak perikardiyal tutulum izlenebilir. Bu durum asemptomatik olabileceği gibi perikardit, perikardiyal efüzyon hatta kardiyak tamponada yol açabilir. Kapak tutulumu, iletim anormallikleri, miyokard infarktüsü, koroner arter tutulumları bildirilmiştir.

En sık görülen kardiyovasküler bulgu ise hastaların üçte ikisinde BT taramasında tespit edilen torasik ve abdominal aort çevresinin infiltrasyonu sonucu oluşan "coated aorta" görünümüdür. Renal arterlerin tutulumu durumunda hastalarda hipertansiyon gelişebilir (3-5).

En sık görülen cilt lezyonu hastaların \%30'unda bulunabilen ksantalezma ve ksantomadır. Bu lezyonlar Juvenil ksantogranüloma (JXG) hastalarında bulunan lezyonlardan morfolojik ve immünohistokimyasal olarak ayırt edilemez $(4,5)$.
ECD tedavisi için şimdiye kadar pek çok farklı tedavi şekli araştırılmışıı. Asemptomatik bazı istisna hasta grupları dışında tüm hastalarda tedavi başlanması önerilmektedir (4). Steroidler, sitotoksik ilaçlar ve otolog hematopoietik kök hücre transplantasyonu ilk tedavi stratejilerindendir ancak klinik etkinlikleri sınırlıdır. Halen yapılmış randomize kontrollü bir çalışma bulunmamaktadır $(4,5)$.

Şu ana kadar kanıtlanmış en çok çalışması bulunan tedavi şekli IFN- $\alpha$ ve pegile IFN- $\alpha$ (PEG-IFN- $\alpha)^{\prime}$ dır. Etkili dozları tutulan organa göre değişmektedir. Özellikle santral sinir sistemi ve kardiyak tutulum görüldüğ̈̈ şiddetli hastalıklarda doz artırımı ve süresiz tedavi önerilmektedir. İlaca bağlı ateş yorgunluk, artralji, depresyon, alopesi, miyelosüpresyon gibi yan etkiler oldukça yaygındır (3-5).

Daha sonra, biyolojik ajanlar ile olumlu sonuçlar elde edilmiştir. Illk olarak, rekombinant IL-1R antagonisti anakinra (1-2 mg/kg/gün) ile bir tedavi denenmiştir. Anakinra tedavisi altında kemik ağrıları ve yorgunluk, halsizlik gibi semptomlarda iyileşme sağlanırken bir hastada kardiyak tutulum tedavi edilmiştir.

Son dönemde ECD hastalarının önemli bir oranındaki BRAFV600E mutasyonunun bulunması yeni terapötik gelişmelere yol açmıştır. Melanom ve hairy cell lösemi tedavisinde kullanılan BRAF inhibitörü vemurafenib ECD hastalarında kullanılmıştır. Olumlu sonuçlar alınmıştır. BRAF mutasyonu tespit edilen ECD hastalarında yeni bir tedavi alternatifi olarak görülmektedir. Ancak tedavinin ne kadar süreceği ve uzun dönem sonuçları hakkında henüz net veriler bulunmamaktadır (5).

\section{SONUÇ}

ECD nadir ve son 10 yıla kadar ihmal edilmiş bir hastalıktır. Klinisyenler, patologlar ve radyologlar arasında farkındalık artıkça yeni olgu bildirimleri oldukça artmıştır. Göğüs hastalıkları doktorları, ECD hastalarında uygun klinikle birlikte spontan pnömotoraks, difüz kistik akciğer hastalığı ve/veya interstisyel akciğer hastalığı belirtilerinin olabileceğini unutmamalı ve tanısal algoritmalarını mutlaka bu yönde genişletmelilerdir.

\section{ÇIKAR ÇATISSMASI}

Yazarlar bu makale ile ilgili herhangi bir çıkar çatışması bildirmemişlerdir. 


\section{YAZAR KATKISI}

Anafikir/Planlama: MBC

Analiz/Yorum: TÖ, YB

Veri sağlama: $M B C$

Yazım: MBC

Gözden Geçirme ve Düzeltme: TÖ, YB

Onaylama: MBC, TÖ

\section{KAYNAKLAR}

1. Cives $M$, Simone V, Rizzo FM, Dicuonzo F, Cristallo Lacalamita M, Ingravallo G, et al. Erdheim-Chester disease: A systematic review. Crit Rev Oncol Hematol 2015;95:1-11.

2. Milne P, Bigley $V$, Bacon CM, Néel A, McGovern N, Bomken $S$, et al. Hematopoietic origin of Langerhans cell histiocytosis and Erdheim-Chester disease in adults. Blood 2017;130:167-75.
3. Haroche J, Arnaud L, Cohen-Aubart F, Hervier B, Charlotte $F$, Emile JF, et al. Erdheim-Chester disease. Curr Rheumatol Rep 2014;16:412.

4. Diamond EL, Dagna L, Hyman DM, Cavalli G, Janku F, Estrada-Veras J, et al. Consensus guidelines for the diagnosis and clinical management of Erdheim-Chester disease. Blood 2014; 124:483-92.

5. Campochiaro C, Tomelleri A, Cavalli G, Berti A, Dagna L. Erdheim-Chester disease. Eur J Int Med 2015;26:223-9.

6. Caglar E, Aktas E, Aribas BK, Sahin B, Terzi A. ErdheimChester disease in thoracic spine: a rare case of compression fracture. Spine J 2016;16:e257-8.

7. Gupta N, Vassallo R, Wikenheiser-Brokamp KA, McCormack FX. Diffuse cystic lung disease - Part I. Am J Respir Crit Care Medi 2015;191:1354-66.

8. Pan Z, Kleinschmidt-DeMasters BK. CNS Erdheim-Chester disease: a challenge to diagnose. I Neuropathol Exp Neurol 2017;76:986-96. 